\title{
Exposure assessment to bisphenol A (BPA) in Portuguese children by human biomonitoring
}

\author{
Luísa Correia-Sá ${ }^{1,2}$ \& Monika Kasper-Sonnenberg ${ }^{3}$ \& André Schütze $^{3}$ \& Claudia Pälmke $^{3}$ \& \\ Sónia Norberto ${ }^{2}$ \& Conceição Calhau ${ }^{2}$ \& Valentina F. Domingues ${ }^{1}$ \& HolgerM. Koch ${ }^{3}$
}

\begin{abstract}
Exposure to bisphenol $A$ (BPA) is known to be widespread and available data suggests that BPA can act as an endocrine disruptor. Diet is generally regarded as the dom- inant BPA exposure source, namely through leaching to food from packaging materials. The aim of this study was to eval- uate the exposure of 110 Portuguese children (4-18 years old), divided in two groups: the regular diet group $(n=43)$ com- prised healthy normal weight/underweight children with no dietary control; the healthy diet group ( $n=67$ ) comprised children diagnosed for obesity/overweight (without other known associated diseases) that were set on a healthy diet for weight control. First morning urine samples were collected and total urinary BPA was analyzed after enzymatic hydrolysis via on-line HPLC-MS/MS with isotope dilution quantifica- tion. Virtually, all the children were exposed to BPA, with $91 \%$ of the samples above the $\mathrm{LOQ}$ (limit of quantification) of $0.1 \mu \mathrm{g} / \mathrm{L}$. The median (95th percentile) urinary BPA levels for nonnormalized and creatinine-corrected values were $1.89 \mu \mathrm{g} / \mathrm{L}$ (16.0) and $1.92 \mu \mathrm{g} / \mathrm{g}$ creatinine (14.4), respectively. BPA levels in the regular diet group were higher than in the healthy diet group,
\end{abstract}

1 REQUIMTE/LAQV - Instituto Superior de Engenharia do Porto do Instituto Politécnico do Porto, Rua Dr. António Bernardino de Almeida, 431, 4200-072 Porto, Portugal

2 CINTESIS - Centro de Investigação em Tecnologias e Sistemas de Informação em Saúde, Centro de Investigação Médica, Faculdade de Medicina da Universidade do Porto, $2^{\circ}$ piso, edif. Nascente, Rua Dr. Plácido da Costa s/n, 4200-450 Porto, Portugal

3 Institute for Prevention and Occupational Medicine of the German Social Accident Insurance - Institute of the Ruhr-University Bochum (IPA), Bürkle-de-la-Camp-Platz 1, 44789 Bochum, Germany but differences were not significant. Calculated daily BPA intakes, however, were significantly higher in children of the regular diet group than in children of healthy diet group. Median (95th percentile) daily intakes amounted to 41.6 (467) $\mathrm{ng} / \mathrm{kg}$ body weight/day in the regular diet group, and 23.2 (197) ng/kg body weight/day in the healthy diet group. Multiple logistic regression analysis re- vealed that children in the healthy diet group had $33 \%$ lower intakes than children in the regular diet group (OR 0.67; 95\% Cl 0.51-0.89). For both groups, however, urinary BPA levels and daily BPA intakes were within the range reported for other children's populations and were well below health guidance values such as the European Food Safety Authority (EFSA) temporary tolerable daily intake (tTDI) of $4 \mu \mathrm{g} / \mathrm{kg}$ body weight/day. In addition, lower daily BPA intakes were more likely linked with the inherent dietary approach rather than with high BMI or obesity.

Keywords Bisphenol A - Exposure assessment . Human biomonitoring $\cdot$ Urine $\cdot$ Children $\cdot$ Diet

\section{Introduction}

Bisphenol A (BPA) was first synthesized in the early twentieth century. However, its beneficial chemical and physical prop- erties as a plasticizer were only discovered later, with the production of epoxy resins and polycarbonate plastics (Geens et al. 2012a). Its industrial production volume is approximately 2.9 million tons per year, making BPA one of the chemicals with the highest production volume worldwide (Aaroe Morck 2012). BPA is used in the production of several consumer products including food/beverage can linings, stor- age containers and packing material (such as paperboard), plastic bags, dental sealants, thermal paper, medical 
equipment, tableware, and toys (Braun and Hauser 2011; Fenichel et al. 2013; Geens et al. 2012a; Hehn 2016; Rubin 2011). BPA can leach from plastic components into food and liquids (Mansilha et al. 2013), and from thermal papers, especially when exposed to high temperatures and acidic or basic conditions (Braun and Hauser 2011; Cao et al. 2011; Correia-Sá et al. 2014; Fenichel et al. 2013; Geens et al. 2010, 2012a, b; Hehn 2016; Li et al. 2013b; Lv et al. 2017; Noonan et al. 2011; Rubin 2011). Diet is generally regarded as the dominant BPA exposure source; however, not all sources and routes of exposure are thoroughly understood (Christensen et al. 2012; Geens et al. 2011, 2012a). Several studies have addressed the impact of die- tary interventions in lowering BPA exposure levels, name- ly by limiting pre-packaged foods (e.g., canned) and in- creasing fresh or organic food (Carwile et al. 2009, 2011; Hagobian et al. 2016; Rudel et al. 2011; Sathyanarayana et al. 2013).

Both free and total BPA (free + conjugated species) have been measured in a variety of human body fluids including urine, blood, saliva, amniotic fluid, and breast milk (Asimakopoulos et al. 2012; Calafat et al. 2005; Koch et al. 2012; Søeborg et al. 2014; Vandenberg et al. 2010; vom Saal and Welshons 2014). Following oral absorption, BPA undergoes rapid first pass metabolism in the intestine and liver, is then conjugated with glucuronic acid (Dekant and Völkel 2008; Teeguarden et al. 2011, 2015a; Völkel et al. 2002, 2005; Yang et al. 2015), and excreted via urine within 24 h. Thus, urine is the preferred matrix for estimating human exposure to BPA (Calafat et al. 2013, 2015; Dekant and Völkel 2008; Koch and Calafat 2009).

BPA is considered an endocrine disruptor (Correia-Sá et al. 2014; Fenichel et al. 2013; Teeguarden and Hanson-Drury 2013) and there is some concern raised by several studies, suggesting a correlation between BPA exposure and health outcomes such as diabetes (Lang et al. 2008; Tai and Chen 2016), decreased sperm quality (Meeker et al. 2010; Vitku et al. 2016), and increased body mass index/weight, obesity, or adiposity (Bhandari et al. 2013; Braun et al. 2014; Hao et al. 2017; Hoepner et al. 2016; Li et al. 2013a; Shankar et al. 2012; Trasande et al. 2012; Vafeiadi et al. 2016; Wang et al. 2012). Regarding obesity, a recent study addressing the effect of low-dose BPA exposure on adipogenesis and adipocytes has concluded that during critical stages of adi- pose tissue development, BPA may cause adipocyte meta- bolic dysfunction and inflammation, increasing the risk of developing obesityrelated diseases (Ariemma et al. 2016). These human health effects from low-level exposures to BPA are currently being discussed (EFSA 2015; Hengstler et al. 2011; Rubin 2011; Teeguarden et al. 2013; Teeguarden and Hanson-Drury 2013; Vandenberg et al. 2009, 2013; Völkel 2017; vom Saal and Welshons 2014). A recent review on child health and BPA exposure classified evidence as "insufficient" because of large inconsistencies in study results (Vrijheid et al. 2016).

The majority of biomonitoring studies on BPA showed a ubiquitous exposure: detection rates in urine, depending on the respective LOQs, are generally above $90 \%$ and median and ranges of exposure are very similar (Bushnik et al. 2010; Calafat et al. 2008; CDC 2015; Covaci et al. 2015; Frederiksen et al. 2013a, b; Geens et al. 2014; Health Canada 2015; Kasper-Sonnenberg et al. 2014, 2012; Koch et al. 2012; LaKind and Naiman 2015; Vandenberg et al. 2010). However, urinary BPA levels in younger children seem to be higher in comparison with adolescents and adults (Becker et al. 2009; Bushnik et al. 2010; Calafat et al. 2008; Frederiksen et al. 2013a). Nevertheless, there is a general lack of data for children, also for European countries and for specific sub-groups such as individuals on a weight management program with a prescribed healthy and calorie restricted/ controlled diet.

Therefore, the general aim of this study was to evaluate BPA exposure in 110 Portuguese children. Currently, in Portugal, human biomonitoring data on BPA are not available. Children were of special interest, because previous studies have reported that, e.g., plasticizer body burdens of children can be higher compared to adults due to increased food intakes in children relative to their body weight or other child related characteristics. Finally, since the study population comprised two groups, one being on a regular diet and the other being on a healthy, balanced diet (obese/overweight children in a weight management program), an additional aim was to assess possible differences in BPA exposures among these two groups and to elucidate if we could indeed observe a lowering effect of a green, healthy diet in a weight management program on BPA exposure levels.

\section{Material and methods}

\section{Study subjects and sample collection}

The present study is part of an ongoing study to assess possible differences between obese/overweight children on a healthy diet to lose/manage weight and normal weight/ underweight children without diet control or constraints in Portugal. Initially, the aim of the study was to determine the exposure to suspected or confirmed (predominantly persistent) endocrine disruptors and/or obesogens. Children were recruited from the pediatric appointment at Hospital de S. João, and several local schools, in 2014 and 2015. Children lived in Oporto and Aveiro, two Portuguese districts, in the North and Central region of the country. One hundred ten children (54 boys, 56 girls) participated in this study with an age range between 4 and 18 years old (arithmetic mean \pm standard deviation $10.41 \pm 3.33$ years old). 

The children were divided in two groups: the group "regular diet" included healthy children which were normal weight/ underweight not changing their regular diet; the group "healthy diet" included children diagnosed for obesity/ overweight without other known associated diseases, counseled for healthy and balanced nutrition and thus set on a prescribed diet, for at least 3 months. First morning urine samples were collected from each participating child. All the specimens were kept cool during transportation and then stored at $-20^{\circ} \mathrm{C}$ until analyses. The study was approved by the ethics committee of the Centro Hospitalar S. João/FMUP (Faculdade de Medicina da Universidade do Porto, ref. 163.13) and all the parents provided written consent.

\section{Determination of urinary creatinine}

Urinary creatinine concentration was measured through a modified Jaffe method (Jaffé 1986) with an Olympus AU5400® Chemistry Analyzer (Beckman-Coulter®, Porto, Portugal) at São João Hospital, Department of Clinical Pathology. Four out of the 110 children had creatinine values below $0.3 \mathrm{~g} / \mathrm{L}$. However, all urine samples were included in the statistical analysis, because creatinine concentrations below a value of $0.3 \mathrm{~g} / \mathrm{L}$ (WHO 1996) (a cutoff for adult populations) in children do not necessarily indicate excessive dilution, but can be indicative of lower muscle mass in children

compared to adults (Barr et al. 2005; Koch et al. 2011).

Analysis of BPA in urine and quality control

Total BPAwas analyzed after enzymatic hydrolysis via on-line HPLC-MS/MS with isotope quantification. The limit of quantification (LOQ) was $0.1 \mu \mathrm{g} / \mathrm{L}$. Details of the method have been described elsewhere (Kasper-Sonnenberg et al. 2012; Koch et al. 2012). Briefly, to a 300- $\mu \mathrm{L}$ aliquots, 150 $\mu \mathrm{L}$ of $1 \mathrm{M}$ ammonium acetate (at $\mathrm{pH} 5.0$ ), $25 \mu \mathrm{L}$ of internal stan- dard, and $6 \mu \mathrm{L}$ of $\beta$-glucuronidase/arylsulfatase were added. Then, the samples were gently mixed and placed in a water bath at $37^{\circ} \mathrm{C}$ for $4 \mathrm{~h}$ for enzymatic hydrolysis. Thereafter, all samples were frozen overnight to precipitate proteins, thawed and equilibrated at room temperature and centrifuged for $10 \mathrm{~min}$. The supernatant was transferred into a second 1.8-mL screw-cap vial. A volume of $25 \mu \mathrm{L}$ was injected into an Agilent Technology LC1200 system coupled with an AB Sciex QTrap 5500 tandem mass spectrometer. We used a two column assembly for chromatographic work-up, with a RAM (Restricted Access Material) column (LiChrospher® RP-8 ADS (25 $\mu \mathrm{m} ; 25$ $\mathrm{mm} \times 4 \mathrm{~mm}$ RAM)) for clean-up and en- richment and, after back flush, an Atlantis T3 analytical col- umn $(3.0 \times 150$ $\mathrm{mm} ; 3 \mu \mathrm{m})$ for chromatographic separation. The mean accuracy for BPA, determined from spiked urine samples (spike level $10 \mu \mathrm{g} / \mathrm{L}$ ), was $96.8 \%$ and relative stan- dard deviations of the laboratory control material at two concentration levels (2.9 and $11.8 \mu \mathrm{g} / \mathrm{L})$ were consistently below $10 \%$. To ensure data accuracy and precision, we included internal quality control samples at two concentration levels, standards, and reagent blanks in each batch of samples. Laboratory blank values of BPA were consistently below the limit of detection of $0.05 \mu \mathrm{g} / \mathrm{L}$. Furthermore, analyses were performed also without enzymatic deconjugation to test for possible external BPA contamination in the pre-analytical phase. The analyzing laboratory has obtained proficiency test- ing certificates in the German External Quality Assessment Scheme (G-EQUAS) and has further served as reference lab- oratory within the European DEMOCOPHES project to en- sure high comparability with other laboratories worldwide (Schindler et al. 2014).

\section{Daily intake estimation}

For the estimation of daily BPA intakes (DIs) from the total urinary levels, we applied a calculation approach based on the creatinine-related BPA concentrations (Koch et al. 2007; Wittassek et al. 2007), adjusted to the height/age dependent reference values for creatinine excretion (Remer et al. 2002). The daily intake in micrograms per kilogram body weight (bw) per day was calculated by the following equation:

$$
\text { DI } \partial \mu \mathrm{g}=\mathrm{kg} \text { bw=dayP } 1 / 4 \frac{\mathrm{UE} \times C E_{1 / 2} g=\text { day }}{\mathrm{FUE} \times \mathrm{BW}} \times \mathrm{MWBPA}
$$

UE is the molar urinary excretion of the measured urinary BPA (in micromole per gram creatinine). The smoothed creatinine excretion rates (CE smoothed) are body height and sex-based reference values for urinary creatinine excretion for healthy, Caucasian, 3-18-year-old children in gram creatinine per day (Remer et al. 2002). FUE is the mass urinary excretion fraction for the analyte (mass of analyte excreted in urine/mass of parent compound ingested); we used a FUE of 1 for BPA (Völkel et al. 2008). MW is the BPA molecular weight and BW the body weight $(\mathrm{kg})$ for each child.

\section{Statistical analysis}

Basic statistical analysis was performed using SPSS 20.0 (IBM Corporation). Several statistical data is presented, such as median, geometric and arithmetic means, maximum values, and percentiles. Concentrations below the LOQ were set to $1 / 2$ LOQ (Lotz et al. 2013). For the present analysis, age was divided in two groups in agreement with the European regulations for clinical studies in pediatric patients (ICH 2000): (i) children from 2 to 11 years old; (ii) adolescents from 12 to 18 years old. For the population's characterization, MannWhitney $U$ tests were performed to assess possible differences across distribution between group 1 and 2 regarding age, sex, weight, height, BMI, and urinary creatinine values. 
As the variables regarding urinary concentrations (creatinine-corrected and non-normalized values) and calculated daily intakes presented a non-normal distribution, nonparametric tests were applied. A Mann-Whitney $U$ test was performed to assess possible differences across distribution between group 1 and 2, for the urinary values $(\mu \mathrm{g} / \mathrm{L}$ and $\mu \mathrm{g} /$ $g$ creatinine) and daily intakes. Statistical analysis for sex and age dependency regarding urinary values was also tested by Mann-Whitney $U$ test. Moreover, the correlation between creatinine ( $\mathrm{g} / \mathrm{L})$ and age was assessed by Spearman's rank correlation.

Multivariate logistic regression analysis was performed using children with regular diet and with healthy diet as dependent and BPA daily intakes ( $\mathrm{ng} / \mathrm{kg}$ bw/day) as independent variable, adjusted for age (years) and sex, and predicting the probability of having a healthy diet. The daily BPA intake was log-transformed by means of logarithm to the basis of 2 . Therefore, its association with the dependent variable was estimated for a doubling of the daily BPA intake in the natural scale. The changes of the dependent variable by a unit change of the independent variables is presented as odds ratios (OR) together with their corresponding 95\% confidence intervals $(95 \% \mathrm{Cl})$ and also as the parameter estimates $\beta$ and their standard errors. This part of the analysis and the boxplot were performed with the statistical software SAS 9.4 (C) SAS Institute Inc., Cary, NC, USA.

For all analyses, a $p$ value $\leq 0.05$ was considered as statistical significant if not otherwise stated.

\section{Results and discussion}

\section{Study population}

BPA concentrations were investigated in 110 urine samples, from 4 to 18 years old Portuguese children. The study group was composed of $51 \%$ girls and $49 \%$ boys, with a median age of 10 years old. The majority of the children was overweight/ obese and underwent a diet with nutritional guidance (healthy diet group) $(61 \% ; n=67)$. From the 43 children of the regular diet group, 42 were normal weight and one child was underweight. More detailed information for the obese/overweight children on a healthy diet and under/normal weight children with a regular diet are given in Table 1. Although the discriminators body weight and BMl differed significantly between the two groups, age, sex, height, and urinary creatinine were evenly distributed (Table 1).

\section{Urinary BPA levels}

From human metabolism studies, we know that BPA is predominantly excreted in its conjugated form (> 99\%); in population studies with stored samples, free BPA (if detectable) is usually below $15 \%$ of total BPA and shares of free BPA higher than $20 \%$ are likely to indicate contamination (Guidry et al. 2015; Koch et al. 2012; Teeguarden et al. 2015b; Völkel et al. 2002; Ye et al. 2015). In all samples from this study, shares of free BPA were below $11 \%$ of total BPA, except in two samples, where free BPA amounted to $>80 \%$ of total BPA (sample 1: total BPA $21.1 \mu \mathrm{g} / \mathrm{L}$, free BPA $17.6 \mu \mathrm{g} / \mathrm{L}$; sample 2: total and free BPA $230 \mu \mathrm{g} / \mathrm{L})$. Consequently, these two samples were excluded from the original study population of 112 children, resulting in 110 children, as described before. In nearly all of the 110 analyzed urine samples (detection rate of $91 \%$ ), BPA (total BPA after enzymatic hydrolysis) was detected. In 10 children, urinary concentrations were below the LOQ of $0.1 \mu \mathrm{g} / \mathrm{L}$. Results (in $\mu \mathrm{g} / \mathrm{L}$ and $\mu \mathrm{g} / \mathrm{g}$ creatinine) for the entire population are shown in Table 2, including median, means, 95th percentile, and maximum. The median concentration was $1.89 \mu \mathrm{g} / \mathrm{L}$, the 95 th percentile $16.0 \mu \mathrm{g} / \mathrm{L}$, and the maximum concentration $66.9 \mu \mathrm{g} / \mathrm{L}$.

Table 1 General characteristics of the studied population

\begin{tabular}{|c|c|c|c|c|c|c|c|c|c|c|}
\hline \multirow[t]{2}{*}{ Population characteristics } & \multicolumn{3}{|c|}{ Regular diet $(n=43)^{\mathrm{a}}$} & \multicolumn{3}{|c|}{ Healthy diet $(n=67)^{\mathrm{a}}$} & \multicolumn{3}{|c|}{ Total population $(n=110)$} & \multirow[t]{2}{*}{$p$ value* } \\
\hline & Median & 95th P. & Max & Median & 95th P. & Max & Median & 95th P. & Max & \\
\hline Age (years) & 11.0 & 17.0 & 18.0 & 9.00 & 15.6 & 17.0 & 10.0 & 16.0 & 18.0 & 0.391 \\
\hline $\operatorname{Sex}(\%)$ & \multicolumn{3}{|c|}{$\begin{array}{l}\text { Female-44\% } \\
\text { Male-56\% }\end{array}$} & \multicolumn{3}{|c|}{$\begin{array}{l}\text { Female-55\% } \\
\text { Male-45\% }\end{array}$} & \multicolumn{3}{|c|}{$\begin{array}{l}\text { Female-51\% } \\
\text { Male-49\% }\end{array}$} & 0.261 \\
\hline Weight (kg) & 34.8 & 64.8 & 75 & 45.5 & 81.9 & 118 & 44.7 & 77.3 & 118 & $<0.001$ \\
\hline Height $(\mathrm{cm})$ & 143 & 181 & 184 & 142 & 167 & 169 & 142 & 169 & 184 & 0.679 \\
\hline BMI $\left(\mathrm{kg} / \mathrm{m}^{2}\right)$ & 17.1 & 22.9 & 24.1 & 24.6 & 32.7 & 42.3 & 22.2 & 29.6 & 42.3 & $<0.001$ \\
\hline Creatinine (g/L) & 0.88 & 2.55 & 2.64 & 0.98 & 2.47 & 3.81 & 0.94 & 2.50 & 3.81 & 0.857 \\
\hline
\end{tabular}

Significant differences between the regular and healthy diet groups $(p \leq 0.05)$ are marked in italics

${ }^{a}$ The underweight/normal weight and obese/overweight groups were defined according to the WHO charters (WHO 2007)

*Mann-Whitney $U$ test, two-tailed 
Table 2 Results of the human biomonitoring study with 110 Portuguese children, aged $4-18(\mu \mathrm{g} / \mathrm{L}$ and $\mu \mathrm{g} / \mathrm{g}$ creatinine); $91 \%$ of samples were above the limit of quantification (LOQ; $0.1 \mu \mathrm{g} / \mathrm{L}$ )

\begin{tabular}{lll}
\hline BPA & $\begin{array}{l}\text { Non-normalized } \\
\text { values }(\mu \mathrm{g} / \mathrm{L})\end{array}$ & $\begin{array}{l}\text { Creatinine-corrected } \\
\text { values }(\mu \mathrm{g} / \mathrm{g})\end{array}$ \\
\hline $\begin{array}{l}\text { Number } \\
\text { Median }\end{array}$ & $n=110$ & \\
$\begin{array}{l}\text { Arithmetic mean } \\
\quad(\mathrm{SD})\end{array}$ & $4.11( \pm 8.91)$ & $3.60( \pm 6.17)$ \\
$\begin{array}{l}\text { Geometric mean } \\
\quad(95 \% \text { CI) }\end{array}$ & $1.58(1.18-2.13)$ & $1.76(1.38-2.41)$ \\
$\begin{array}{l}\text { Percentile 95th } \\
\text { Maximum }\end{array}$ & 16.0 & 14.4 \\
\hline
\end{tabular}

SD standard deviation of the arithmetic mean, $95 \%$ CI 95\% confidence interval

Detailing the investigation further we checked whether sex, study group (regular diet vs. healthy diet) or age would influence urinary BPA concentrations (both in $\mu \mathrm{g} / \mathrm{L}$ and $\mu \mathrm{g} / \mathrm{g}$ creatinine). The results are depicted in Table 3.

No significant differences were found regarding sex, age, or study group for BPA urinary concentrations (both adjusted and non-adjusted values). However, the children in the regular diet group had approximately $20 \%$ higher urinary BPA concentrations than the children in the healthy diet group, both in $\mu \mathrm{g} / \mathrm{L}$ (median 2.28 vs. $1.87 \mu \mathrm{g} / \mathrm{L}$ ) and after creatinine adjustment (median 2.14 vs. $1.76 \mu \mathrm{g} / \mathrm{g}$ ). Albeit not significant, the small difference between the groups may reflect differences in external BPA exposure, as children with healthy diet were being followed in a nutritional appointment. The healthy diet relied primarily on fresh food and less on processed and packaged food items. Additionally, the amount of calories was set accord- ing to their nutritional needs. Contrary to this group, chil- dren with regular diet continued their usual diet.
Table 4 Daily intake of BPA (ng/kg bw/day) in Portuguese children

\begin{tabular}{|c|c|c|c|}
\hline \multirow[t]{2}{*}{ BPA } & \multirow{2}{*}{$\begin{array}{l}\text { Total population } \\
n=110\end{array}$} & \multicolumn{2}{|l|}{ Study group } \\
\hline & & $\begin{array}{l}\text { Regular diet } \\
(n=43)\end{array}$ & $\begin{array}{l}\text { Healthy diet } \\
(n=67)\end{array}$ \\
\hline Median & 31.3 & 41.6 & 23.2 \\
\hline $\begin{array}{l}\text { Percentile } \\
\text { 95th }\end{array}$ & 221 & 467 & 197 \\
\hline Maximum & 624 & 624 & 578 \\
\hline$p$ value* & - & 0.002 & \\
\hline
\end{tabular}

Significant differences $(p \leq 0.05)$ are marked in italics

${ }^{*}$ Mann-Whitney $U$ test, two-tailed

Regarding influence of age, urinary concentration values in micrograms per liter in older children (12-18 years old) were found to be higher than in younger children (4-11 years old) with median concentrations of 2.25 and $1.87 \mu \mathrm{g} / \mathrm{L}$, respectively. Creatinine adjustment inverted this outcome and led to higher BPA concentrations in younger children compared to older ones, with median concentrations of 2.10 and of $1.76 \mu \mathrm{g} / \mathrm{g}$ creatinine, respectively. In both cases, however, differences were not statistically significant. The results are in agreement with reports from other studies (Bushnik et al. 2010; Calafat et al. 2008). The reversing effect between micrograms per liter and micrograms per gram creatinineadjusted concentrations is probably due to the fact that creatinine excretion itself is highly correlated with children's age and development (Barr et al. 2005; Remer et al. 2002).

\section{Daily BPA intakes}

For the total study population, the median daily BPA intake was $31.3 \mathrm{ng} / \mathrm{kg}$ bw/day (95th percentile $221 \mathrm{ng} / \mathrm{kg}$ bw/day;

Table 3 Total BPA urinary levels for the Portuguese children ( $\mu \mathrm{g} / \mathrm{L}$ and $\mu \mathrm{g} / \mathrm{g}$ creatinine) according to age ranges, sex, and study groups

\begin{tabular}{|c|c|c|c|c|c|c|}
\hline \multirow{2}{*}{ BPA } & \multicolumn{2}{|l|}{ Sex } & \multicolumn{2}{|l|}{ Age } & \multicolumn{2}{|l|}{ Study group } \\
\hline & Boys $(n=54)$ & Girls $(n=56)$ & $4-11$ years $(n=70)$ & $12-18$ years $(n=40)$ & Regular diet $(n=43)$ & Healthy diet $(n=67)$ \\
\hline \multicolumn{7}{|c|}{ Non-normalized values $(\mu \mathrm{g} / \mathrm{L})$} \\
\hline Median & 2.20 & 1.86 & 1.87 & 2.25 & 2.28 & 1.87 \\
\hline Percentile 95th & 20.6 & 16.1 & 16.0 & 16.5 & 29.1 & 16.0 \\
\hline Maximum & 66.9 & 54.6 & 54.6 & 66.9 & 66.9 & 54.6 \\
\hline$p$ value* & 0.318 & & 0.056 & & 0.134 & \\
\hline \multicolumn{7}{|c|}{ Creatinine-corrected values $(\mu \mathrm{g} / \mathrm{g})$} \\
\hline Median & 2.01 & 1.79 & 2.10 & 1.76 & 2.14 & 1.76 \\
\hline Percentile 95th & 19.8 & 12.9 & 18.6 & 6.01 & 23.1 & 14.8 \\
\hline Maximum & 31.0 & 46.0 & 46.0 & 25.9 & 31.0 & 46.0 \\
\hline$p$ value* & 0.211 & & 0.488 & & 0.158 & \\
\hline
\end{tabular}

*Mann-Whitney $U$ test, two-tailed 
Fig. 1 Daily intakes of BPA (ng/ $\mathrm{kg}$ bw/day) in the two study groups

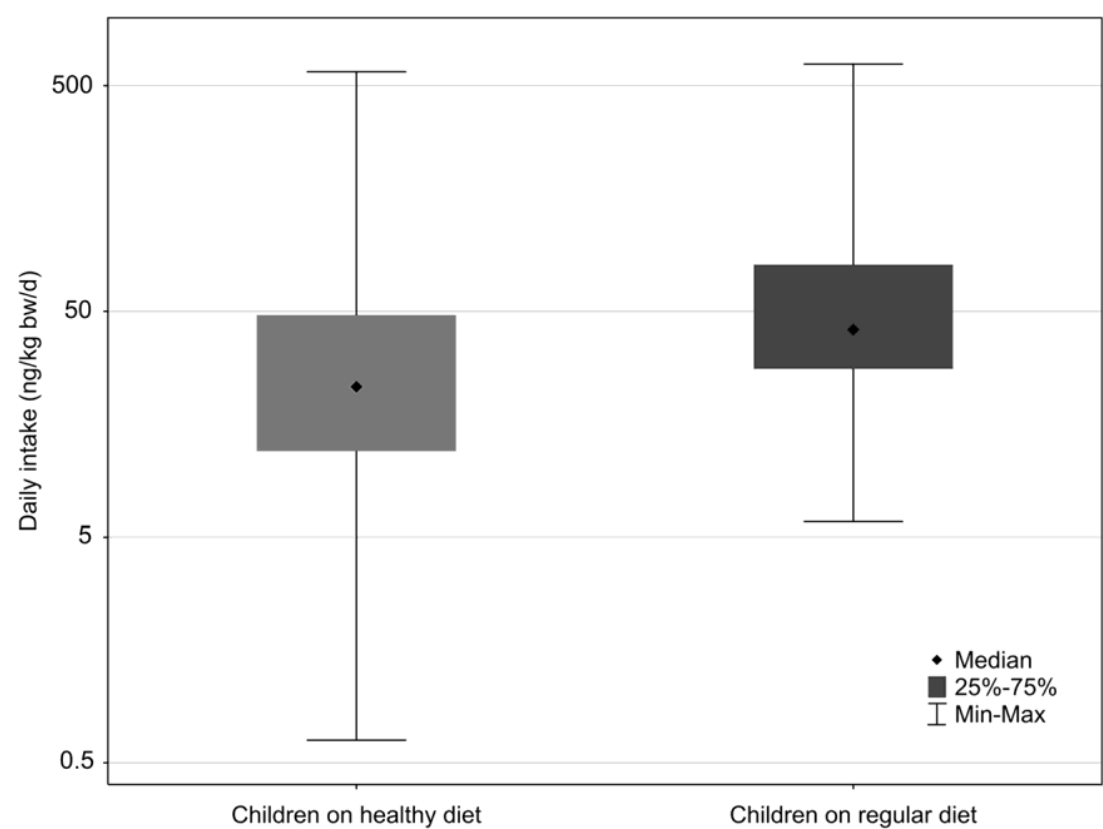

maximum $624 \mathrm{ng} / \mathrm{kg}$ bw/day). Detailed results for the different study groups are shown in Table 4.

The children on a regular diet had significantly higher daily BPA intakes than the children on a healthy diet (Table 4 and Fig. 1). Median (95th percentiles) daily intakes were 41.6 (467) and 23.2 (197) ng/kg bw/day for regular and healthy diet group, respectively.

In younger children (4-11 years), the median creatinine value $(0.80 \mathrm{~g} / \mathrm{L})$ was significantly lower than in older children (12-18 years; $1.37 \mathrm{~g} / \mathrm{L})$, and creatinine was positively correlated with the children's age (Spearman's correlation coefficient $r 0.533 ; p$ value $\leq 0.01$ ). The effect of rapidly changing child physiology with age, however, was accounted for in the daily intake calculations by using height/age dependent reference values for creatinine excretion.

To further investigate the influence of the diet on the BPA daily intakes, a multiple logistic regression analysis was performed. The associations between children with regular and healthy diet (dependent variable, outcome) and the Dls, adjusting for sex and age, were analyzed and the results are presented in Table 5.
The model indicated that daily BPA intakes were significantly associated with children with a healthy diet. Approximately $33 \%$ lower daily intakes were predicted for the healthy diet group compared to the regular diet group (OR 0.67; 95\% Cl 0.51-0.89).

As highlighted by other authors regarding chemicals with short half-lives, and food as an important exposure source, a healthy diet can have an impact by lowering exposure (Christensen et al. 2012; Hagobian et al. 2016; Rudel et al. 2011; Sathyanarayana et al. 2013). Thus, the different dietary patterns may explain some of the differences between the two groups. However, we have to point out that, next to diet, the physical characteristics of the two groups were considerably different with $61 \%$ obese and 39\% normal-/underweight children. Renal clearance itself is also influenced to some extent by the physiological differences (namely BMI) between both groups (Hays et al. 2015).

Dietary sources seem to most likely constitute $2 / 3$ of general BPA background exposure in humans, with only $1 / 3$ of BPA exposure attributable to other sources (Christensen et al. 2012). Dust, thermal paper, dental and medical materials have

Table 5 Multiple logistic regression analyses of the diet groups (regular and healthy diet) and associations with the daily BPA intakes (ng/kg bw/day)

\begin{tabular}{|c|c|c|c|c|}
\hline Model & $\beta(\mathrm{SE})$ & Lower $95 \%$ CI & Odds ratio (OR) & Upper $95 \% \mathrm{CI}$ \\
\hline Daily intakes (ng/kg bw/day) ${ }^{\mathrm{a}}$ & $-0.40(0.14)^{*}$ & 0.51 & 0.67 & 0.89 \\
\hline Age (years) & $-0.07(0.06)$ & 0.82 & 0.93 & 1.05 \\
\hline Sex & $0.33(0.42)$ & 0.61 & 1.39 & 3.13 \\
\hline
\end{tabular}

$\beta$ estimate beta, SE standard error, 95\% CI 95\% confidence interval

${ }^{a}$ Unit of exposure change $=$ doubling the daily BPA intake $(\log 2)$

*Significance level is $p \leq 0.05$ 
been identified as relevant non-dietary sources of BPA (Biedermann et al. 2010; Geens et al. 2012a, b; Hehn 2016). Contamination of food with BPA is possible to occur dur- ing the production process or when packaging by contact with materials containing epoxy resins and polycarbonate materials. Dietary BPA exposure may depend more on food packaging material than the food item per se. For example, canned food has been shown to contain higher BPA levels than uncanned or unprocessed food items (Cao et al. 2009; Cunha et al. 2011, 2012; Cunha and Fernandes 2013; Larsson et al. 2014; Noonan et al. 2011). Other authors confirmed the presence of BPA in paper and cardboard used as food containers (Lopez-Espinosa et al. 2007). Several epidemiological studies support the association between urinary BPA levels and food consumption (Cao et al. 2011; Casas et al. 2013; Christensen et al. 2012; Lakind and Naiman 2011; Quirós-Alcalá et al. 2013; Teeguarden et al. 2011).

BPA exposure has also been reported to be associated with an increase in body weight and BMl ( $\mathrm{Li}$ et al. 2013a; Shankar et al. 2012; Trasande et al. 2012; Wang et al. 2012). Since diet is a major source of BPA exposure, reverse causality cannot be excluded, as obese children may have greater exposure to BPA due to higher dietary intakes or differently concentrated urines (Hays et al. 2015; Hoepner et al. 2016). In this study, the overweight/obese children (who were on a healthy diet for weight loss/management) had lower BPA exposures than nor- mal-/underweight weight children (with regular diet). This outcome supports Hoepner et al. 2016 suspicion that previous cross-sectional studies could be biased due to associations between BMI and higher food intake, leading to higher expo- sures to BPA from food. Since obese or overweight children were on dietary restriction, their healthy and balanced nutri- tion, based on fresh food and less packaged and processed food items, provided a plausible explanation to their lower BPA exposure.

\section{Risk assessment}

For risk assessment, both urinary BPA levels and calculated BPA daily intakes were compared with health based guidance values. The German Human Biomonitoring (HBM) Commission defined a provisional HBM value for BPA in children's urine of $1500 \mu \mathrm{g} / \mathrm{L}$ (HBM 2012) that was updated and lowered to $100 \mu \mathrm{g} / \mathrm{L}$ in 2015 (Apel et al. 2016), taking into account the BPA re-evaluation of EFSA (EFSA 2015). In our study population, the 95th percentile was $16.0 \mu \mathrm{g} / \mathrm{L}$ and the maximum was $66.9 \mu \mathrm{g} / \mathrm{L}$ (Table 2). Thus, all urinary BPA concentrations in the study were below this HBM value.

In 2015, the European tolerable daily intake (TDI) for BPA was lowered to $4 \mu \mathrm{g} / \mathrm{kg}$ of bw/day by EFSA (EFSA 2015). All daily BPA intakes calculated in our study were below this TDI, with a 95th percentile of $0.22 \mu \mathrm{g} / \mathrm{kg}$ bw/day and a maximum of $0.62 \mu \mathrm{g} / \mathrm{kg}$ bw/day (Table 4).
First morning urine samples were the only bio-specimen available in this study. First morning urine samples have been previously shown to some extent to underestimate exposures to BPA (Teeguarden et al. 2011). Food related exposures during lunch or dinner (from the day before) may be underrepresented in these samples due to the rapid BPA elimination kinetics. Even considering this hypothetical underestimation, daily intake levels of BPA for the Portuguese children can currently be classified as safe.

BPA daily intakes were calculated based upon urinary levels, taking into account the body height and sex based reference values for urinary creatinine excretion (Remer et al. 2002; Wittassek et al. 2007). As a note of caution, it is important to highlight that all reference values were derived from standard weight children (Remer et al. 2002) and their applicability to obese/overweight children has not been studied before. Urinary flow rate and also creatinine were found to be influence by age, sex and BMI category (Barr et al. 2005; Hays et al. 2015). Finally, variations in hydration status have also to be recognized as an important source of variability in measured urinary concentrations (Hays et al. 2015).

\section{International comparison}

To our knowledge, this is the first BPA biomonitoring study performed on Portuguese children. Only one other study reported preliminary results for Portugal, on 20 adult volunteers (Cunha and Fernandes 2010). Worldwide, BPA in urine has been analyzed in numerous studies of the general population (or specific subpopulations) reviewed by several authors (Dekant and Völkel 2008; Vandenberg et al. 2010). A comprehensive review of all biomonitoring data for BPA in all populations is beyond the scope of this paper. In Table 6, this study's data was compared with other studies performed in child populations.

Our data, both in terms of urinary BPA levels and calculated daily intakes, is in accordance with other studies on children in Europe and other parts of the world. Median urinary BPA concentrations are within a range of 1 to $3 \mu \mathrm{g} / \mathrm{L}$ and median daily BPA intakes are consistently below $0.1 \mu \mathrm{g} / \mathrm{kg}$ bw/day.

The European DEMOCOPHES project (Covaci et al. 2015) provided BPA exposure data for 6-11 year-old children from six European countries (Belgium, Denmark, Luxembourg, Slovenia, Spain, and Sweden). The population in the present study had a very similar urinary BPA concentration $(1.89 \mu \mathrm{g} / \mathrm{L})$ when compared with overall DEMOCOPHES median $(1.96 \mu \mathrm{g} / \mathrm{L})$. Furthermore, exposures in Portuguese children are similar to exposures in the Spanish DEMOCOPHES children $(1.91 \mu \mathrm{g} / \mathrm{L})$; Spain is Portugal's sole land border in the Iberian Peninsula. Daily intake calculations in the DEMOCOPHES approach are in agreement with our calculated data. 
Table 6 Overview of worldwide biomonitoring studies for BPA concentrations $(\mu \mathrm{g} / \mathrm{L})$ in child populations

\begin{tabular}{|c|c|c|c|c|c|c|c|}
\hline Country & Number & Population characteristics & Sampling years & $\operatorname{Median}(\mu \mathrm{g} / \mathrm{L})$ & DI calculation model & $\begin{array}{l}\text { Daily intake } \\
\text { (ng/kg bw/day) }\end{array}$ & References \\
\hline Portugal (all) & 110 & $\begin{array}{l}\text { 4-18 years old (obese/overweight and } \\
\text { normal weight/underweight with or } \\
\text { witnout a diet control) }\end{array}$ & $2014 / 2015$ & 1.89 & Creatinine-based & 31.3 & This study \\
\hline Belgium—DEMOCOPHES & 125 & $\begin{array}{l}6-11 \text { years } \\
6-12 \text { years for Slovenia }\end{array}$ & $2011 / 2012$ & $2.27^{\mathrm{a}}$ & $\begin{array}{l}\text { Creatinine output } \\
\text { Fixed urinary output }\end{array}$ & $\begin{array}{l}39.9 \\
46.7\end{array}$ & (Covaci et al. 2015) \\
\hline \multirow[t]{2}{*}{ Denmark—DEMOCOPHES } & 142 & & & $1.71^{\mathrm{a}}$ & Creatinine output & 40.2 & \\
\hline & & & & & Fixed urinary output & 37.6 & \\
\hline \multirow[t]{2}{*}{ Luxembourg—DEMOCOPHES } & 59 & & & $1.38^{\mathrm{a}}$ & Creatinine output & 37.8 & \\
\hline & & & & & Fixed urinary output & 30.0 & \\
\hline \multirow[t]{2}{*}{ Slovenia-DEMOCOPHES } & 112 & & & $3.30^{\mathrm{a}}$ & Creatinine output & 49.9 & \\
\hline & & & & & Fixed urinary output & 59.7 & \\
\hline \multirow{2}{*}{ Spain-DEMOCOPHES } & 118 & & & $1.91^{\mathrm{a}}$ & Creatinine output & 40.2 & \\
\hline & & & & & Fixed urinary output & 34.9 & \\
\hline \multirow[t]{2}{*}{ Sweden—DEMOCOPHES } & 97 & & & $1.31^{\mathrm{a}}$ & Creatinine output & 30.6 & \\
\hline & & & & & Fixed urinary output & 25.0 & \\
\hline \multirow[t]{2}{*}{ DEMOCOPHES all } & 653 & $6-11$ years & & $1.96^{\mathrm{a}}$ & Creatinine output & 38.2 & \\
\hline & & $6-12$ years for Slovenia & & & Fixed urinary output & 37.9 & \\
\hline \multirow[t]{3}{*}{ Germany } & 599 & $3-14$ years & $2007 / 2008$ & 2.74 & $\begin{array}{l}\text { Volume-based } \\
\text { Creatinine-based }\end{array}$ & $\begin{array}{l}\text { GM } 60.0 \\
\text { GM } 50.0\end{array}$ & (Becker et al. 2009) \\
\hline & 465 & $8-10$ years & $2009 / 2010$ & 2.04 & n.a. & n.a. & $\begin{array}{l}\text { (Kasper-Sonnenberg } \\
\text { et al. 2014) }\end{array}$ \\
\hline & 104 & $6-8$ years & $2006 / 2009$ & 2.30 & n.a & n.a & $\begin{array}{l}\text { (Kasper-Sonnenberg } \\
\text { et al. 2012) }\end{array}$ \\
\hline \multirow[t]{2}{*}{ Denmark } & 143 & $\begin{array}{l}\text { Urban and rural resident children } \\
6-11 \text { years }\end{array}$ & 2011 & 1.70 & $\begin{array}{l}\text { Creatinine-based- } \\
\text { urban } \\
\text { Creatinine-based-rural }\end{array}$ & $\begin{array}{l}38.0 \\
43.0\end{array}$ & $\begin{array}{l}\text { (Frederiksen et al. } \\
\text { 2013b) }\end{array}$ \\
\hline & $\begin{array}{l}49 \\
55\end{array}$ & $\begin{array}{l}6-10 \text { years } \\
11-16 \text { years }\end{array}$ & 2007 & $\begin{array}{l}2.78 \\
0.81\end{array}$ & 24-h urine & $\begin{array}{l}66.6 \\
15.2\end{array}$ & $\begin{array}{l}\text { (Frederiksen et al. } \\
\text { 2013a) }\end{array}$ \\
\hline Belgium & 193 & $14-15$ years & $2008 / 2009$ & 2.21 & n.a & n.a & (Geens et al. 2014) \\
\hline Spain & 130 & 4 years & $2008 / 2010$ & 3.10 & n.a & n.a & (Casas et al. 2013) \\
\hline \multirow[t]{2}{*}{ Canada } & $\begin{array}{r}1031 \\
980\end{array}$ & $\begin{array}{l}6-11 \text { years } \\
12-19 \text { years }\end{array}$ & $2007 / 2009$ & $\begin{array}{l}\text { GM } 1.30 \\
\text { GM } 1.50\end{array}$ & $\begin{array}{l}\text { n.a } \\
\text { n.a }\end{array}$ & $\begin{array}{l}\text { n.a } \\
\text { n.a }\end{array}$ & (Bushnik et al. 2010) \\
\hline & $\begin{array}{r}1004 \\
992\end{array}$ & $\begin{array}{l}6-11 \text { years } \\
12-19 \text { years }\end{array}$ & $2012 / 2013$ & $\begin{array}{l}1.20 \\
1.40\end{array}$ & $\begin{array}{l}\text { n.a } \\
\text { n.a }\end{array}$ & $\begin{array}{l}\text { n.a } \\
\text { n.a }\end{array}$ & $\begin{array}{l}\text { (Health Canada } \\
\text { 2015) }\end{array}$ \\
\hline \multirow[t]{2}{*}{ USA } & $\begin{array}{l}409 \\
462\end{array}$ & $\begin{array}{l}6-11 \text { years } \\
12-19 \text { years }\end{array}$ & $2013 / 2014$ & $\begin{array}{l}1.40 \\
1.20\end{array}$ & $\begin{array}{l}\text { n.a } \\
\text { n.a }\end{array}$ & $\begin{array}{l}\text { n.a } \\
\text { n.a }\end{array}$ & (CDC 2015) \\
\hline & 356 & $6-11$ years & $2005 / 2006$ & 2.70 & & 51.3 & \\
\hline
\end{tabular}




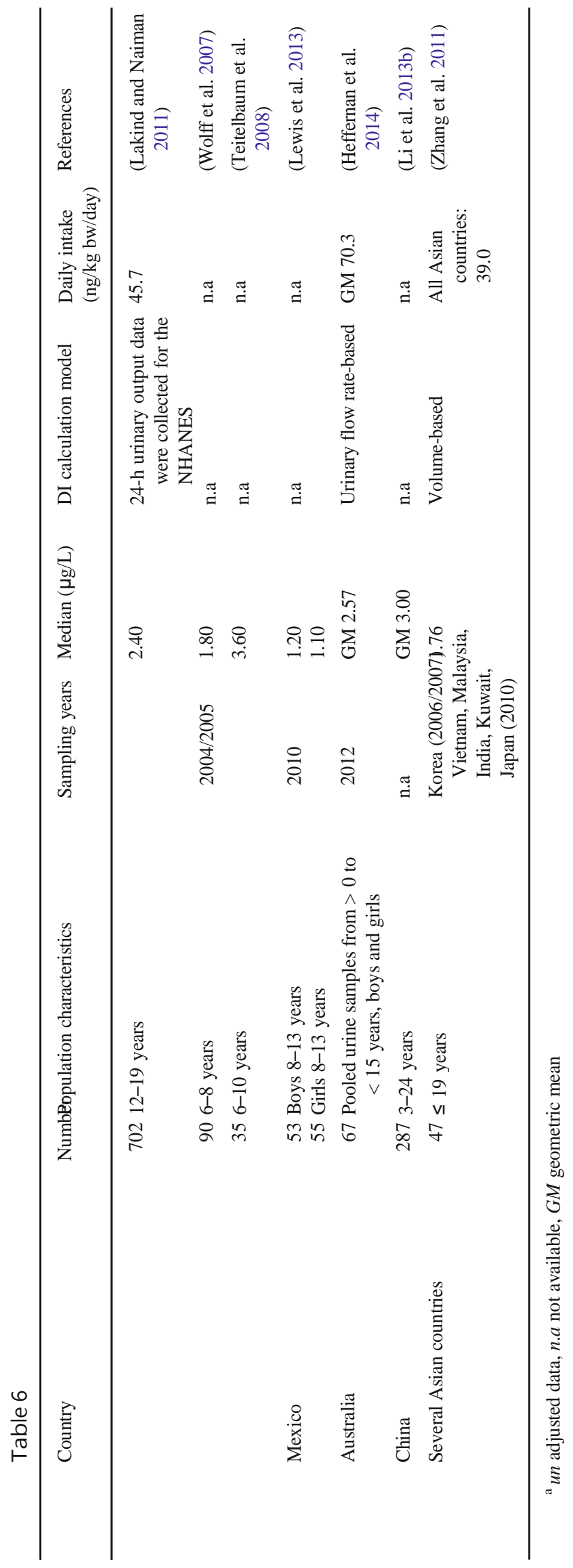

Some limitations of this study should be noted. The complex nature of the original study design (determination of exposure to suspected or confirmed predominantly persistent endocrine disruptor and/or obesogens) was less suitable to analyze effect-modifications with urinary BPA concentrations because of its short half-life. BPA as potential obesogen has been included after the study population was enrolled and nutritional guidance took place. Therefore, urine samples were not collected before the nutritional guidance started, nor a dietary questionnaire was applied, and thus, it was not possible to address the direct effect of the type of the diet to the exposure levels. Nevertheless, the strength of this study lies on the analysis of BPA exposures in obese/overweight children on a healthy diet compared with the other children on a regular diet. Although the initial study design was not perfectly adapted to these questions, evidence is provided that BPA intake is more likely associated with an increased intake of contaminated food rather than a direct correlation between BPA exposures and the occurrence or development of obesity in children.

\section{Conclusion}

With this study, we could confirm that BPA exposure in Portuguese children is within the range of exposures in Europe or other populations of the Globe previously investigated. We found evidence that BPA intake depends to some extent on the diet, with children on a dietary program (healthy diet) for weight loss/management revealing 33\% lower daily intakes compared to children on their regular diet. Thus, contaminated food is likely to be an important but not the only source of BPA exposure for the Portuguese children studied. Notwithstanding, none of the children exceeded any of the health guidance values (HBM-I, TDI) derived for BPA.

Acknowledgements Luísa Correia-Sá is grateful to Fundação para a Ciência e a Tecnologia (FCT) by the grant (SFRH/BD/87019/2012), financed by $\mathrm{POCH}$, subsidized by Fundo Social Europeu and Ministério da Ciência, Tecnologia e Ensino Superior.

The authors are thankful to the project Qualidade e Segurança Alimentar - uma abordagem (nano)tecnológica, reference NORTE-01-0145-FEDER000011.

Compliance with ethical standards The study was designed in ac-cordance with the ethical standards of the institutional and/or national research committee and with the 1964 Helsinki Declaration and its later amendments or comparable ethical standards. Approval for the study protocol was obtained from the Ethics Commission of the Faculdade de Medicina da Universidade do Porto, Portugal (ref. 163.13). Written informed consent was obtained from all parents of individual participants included in the study. 


\section{References}

Aaroe Morck T (2012) Chapter 3G Bisphenol A. In: Knudsen L, Domenicom FM (eds) Biomarkers and Human Biomonitoring, vol 1. The Royal Society of Chemistry, pp 360-380. https://doi.org/10. 1039/9781849733373-00360

Apel P, Angerer J, Wilhelm M, Kolossa-Gehring M (2016) New HBM values for emerging substances, inventory of reference and HBM values in force, and working principles of the German Human Biomonitoring Commission. Int J Hyg Environ Health 220:152166. https://doi.org/10.1016/j.ijheh.2016.09.007

Ariemma F, D'Esposito V, Liguoro D, Oriente F, Cabaro S, Liotti A, Cimmino I, Longo M, Beguinot F, Formisano P, Valentino R (2016) Low-Dose Bisphenol-A Impairs Adipogenesis and Generates Dysfunctional 3T3-L1 Adipocytes. PLoS One 11: e0150762. https://doi.org/10.1371/journal.pone.0150762

Asimakopoulos AG, Thomaidis NS, Koupparis MA (2012) Recent trends in biomonitoring of bisphenol A, 4-t-octylphenol, and 4nonylphenol. Toxicol Lett 210:141-154. https://doi.org/10.1016/j. toxlet.2011.07.032

Barr DB, Wilder LC, Caudill SP, Gonzalez AJ, Needham LL, Pirkle JL (2005) Urinary Creatinine Concentrations in the U.S. Population: Implications for Urinary Biologic Monitoring Measurements. Environ Health Perspect 113:192-200. https://doi.org/10.1289/ehp. 7337

Becker K, Goeen T, Seiwert M, Conrad A, Pick-Fuss H, Mueller J, Wittassek M, Schulz C, Kolossa-Gehring M (2009) GerES IV: Phthalate metabolites and bisphenol A in urine of German children. Int J Hyg Environ Health 212:685-692. https://doi.org/10.1016/j. ijheh.2009.08.002

Bhandari R, Xiao J, Shankar A (2013) Urinary Bisphenol A and Obesity in US Children. Am J Epidemiol 177:1263-1270. https://doi.org/10. 1093/aje/kws391

Biedermann S, Tschudin P, Grob K (2010) Transfer of bisphenol A from thermal printer paper to the skin. Anal Bioanal Chem 398:571-576. https://doi.org/10.1007/s00216-010-3936-9

Braun JM, Hauser R (2011) Bisphenol A and children's health. Curr Opin Pediatr 23:233-239. https://doi.org/10.1097/MOP. 0b013e3283445675

Braun JM, Lanphear BP, Calafat AM, Deria S, Khoury J, Howe CJ, Venners SA (2014) Early-life bisphenol A exposure and child body mass index: a prospective cohort study. Environ Health Perspect 122:1239-1245. https://doi.org/10.1289/ehp.1408258

Bushnik T, Haines D, Levallois P, Levesque J, Van Oostdam J, Viau C (2010) Lead and bisphenol A concentrations in the Canadian population. Health Rep 21:7-18

Calafat AM, Kuklenyik Z, Reidy JA, Caudill SP, Ekong J, Needham LL (2005) Urinary Concentrations of Bisphenol A and 4-Nonylphenol in a Human Reference Population. Environ Health Perspect 113: 391-395. https://doi.org/10.1289/ehp. 7534

Calafat AM, Ye X, Wong L-Y, Reidy JA, Needham LL (2008) Exposure of the U.S. Population to Bisphenol A and 4-tertiary-Octylphenol: 2003-2004. Environ Health Perspect 116:39-44. https://doi.org/10. 1289/ehp. 10753

Calafat AM, Koch HM, Swan SH, Hauser R, Goldman LR, Lanphear BP, Longnecker MP, Rudel RA, Teitelbaum SL, Whyatt RM, Wolff MS (2013) Misuse of blood serum to assess exposure to bisphenol A and phthalates. Breast Cancer Res 15:403-403. https://doi.org/10.1186/ bcr3494

Calafat AM, Longnecker MP, Koch HM, Swan SH, Hauser R, Goldman LR (2015) Optimal exposure biomarkers for nonpersistent chemicals in environmental epidemiology. Environ Health Perspect 123:A166-A168. https://doi.org/10.1289/ehp. 1510041
Cao X-L, Corriveau J, Popovic S (2009) Levels of Bisphenol A in Canned Soft Drink Products in Canadian Markets. J Agric Food Chem 57:1307-1311. https://doi.org/10.1021/jf803213g

Cao XL, Perez-Locas C, Dufresne G, Clement G, Popovic S, Beraldin F, Dabeka RW, Feeley M (2011) Concentrations of bisphenol A in the composite food samples from the 2008 Canadian total diet study in Quebec City and dietary intake estimates. Food Addit Contam A 28: 791-798. https://doi.org/10.1080/19440049.2010.513015

Carwile JL, Luu HT, Bassett LS, Driscoll DA, Yuan C, Chang JY, Ye X, Calafat AM, Michels KB (2009) Polycarbonate Bottle Use and Urinary Bisphenol A Concentrations. Environ Health Perspect 117:1368-1372. https://doi.org/10.1289/ehp.0900604

Carwile JL, Ye X, Zhou X, Calafat AM, Michels KB (2011) Canned Soup Consumption and Urinary Bisphenol A: A Randomized Crossover Trial. JAMA 306:2218-2220. https://doi.org/10.1001/jama.2011. 1721

Casas M, Valvi D, Luque N, Ballesteros-Gomez A, Carsin A-E, Fernandez MF, Koch HM, Mendez MA, Sunyer J, Rubio S, Vrijheid M (2013) Dietary and sociodemographic determinants of bisphenol A urine concentrations in pregnant women and children. Environ Int 56:10-18. https://doi.org/10.1016/j.envint.2013.02.014

CDC (2015) Fourth National Report on Human Exposure to Environmental Chemicals - Updated Tables, January 2017, Volume One. https://www.cdc.gov/biomonitoring/pdf/ FourthReport_UpdatedTables_Volume1_Jan2017.pdf. Accessed 8 Mar 2017

Christensen KLY, Lorber M, Koslitz S, Brüning T, Koch HM (2012) The contribution of diet to total bisphenol A body burden in humans: Results of a 48 hour fasting study. Environ Int 50:7-14. https://doi. org/10.1016/j.envint.2012.09.002

Correia-Sá L, Calhau C, Delerue-Matos C, Domingues VF (2014) Chapter 3: BPA Evaluation in Human Samples. In: Gibert Y (ed) Bisphenol A: Sources, Risks of Environmental Exposure and Human Health Effects. Nova Science Publishers, New York, pp $33-124$

Covaci A, Hond ED, Geens T, Govarts E, Koppen G, Frederiksen H, Knudsen LE, Mørck TA, Gutleb AC, Guignard C, Cocco E, Horvat M, Heath E, Kosjek T, Mazej D, Tratnik JS, Castaño A, Esteban M, Cutanda F, Ramos JJ, Berglund M, Larsson K, Jönsson BAG, Biot P, Casteleyn L, Joas R, Joas A, Bloemen L, Sepai O, Exley K, Schoeters G, Angerer J, Kolossa-Gehring M, Fiddicke U, Aerts D, Koch HM (2015) Urinary BPA measurements in children and mothers from six European member states: Overall results and determinants of exposure. Environ Res 141:77-85. https://doi.org/10.1016/j.envres.2014.08.008

Cunha SC, Fernandes JO (2010) Quantification of free and total bisphenol A and bisphenol B in human urine by dispersive liquidliquid microextraction (DLLME) and heart-cutting multidimensional gas chromatography-mass spectrometry (MD-GC/MS). Talanta 83:117-125. https://doi.org/10.1016/j.talanta.2010.08.048

Cunha SC, Fernandes JO (2013) Assessment of bisphenol A and bisphenol B in canned vegetables and fruits by gas chromatography-mass spectrometry after QuEChERS and dispersive liquid-liquid microextraction. Food Control 33:549-555. https://doi.org/10. 1016/j.foodcont.2013.03.028

Cunha SC, Almeida C, Mendes E, Fernandes JO (2011) Simultaneous determination of bisphenol A and bisphenol B in beverages and powdered infant formula by dispersive liquid-liquid micro-extraction and heart-cutting multidimensional gas chromatography-mass spectrometry. Food Addit Contam A 28:513-526. https://doi.org/10.1080/ 19440049.2010.542551

Cunha SC, Cunha C, Ferreira AR, Fernandes JO (2012) Determination of bisphenol A and bisphenol B in canned seafood combining QuEChERS extraction with dispersive liquid-liquid microextraction followed by gas chromatography-mass spectrometry. Anal Bioanal Chem 404:2453-2463. https://doi.org/10.1007/s00216-012-6389-5 
Dekant W, Völkel W (2008) Human exposure to bisphenol A by biomonitoring: Methods, results and assessment of environmental exposures. Toxicol Appl Pharmacol 228:114-134. https://doi.org/10. 1016/j.taap.2007.12.008

EFSA (2015) Processing, Aids Scientific Opinion on the risks to public health related to the presence of bisphenol A (BPA) in foodstuffs. EFSA J 13:3978. https://doi.org/10.2903/j.efsa.2015.3978

Fenichel P, Chevalier N, Brucker-Davis F (2013) Bisphenol A: An endocrine and metabolic disruptor. Ann Endocrinol 74:211-220. https:// doi.org/10.1016/j.ando.2013.04.002

Frederiksen H, Aksglaede L, Sorensen K, Nielsen O, Main KM, Skakkebaek NE, Juul A, Andersson A-M (2013a) Bisphenol A and other phenols in urine from Danish children and adolescents analyzed by isotope diluted TurboFlow-LC-MS/MS. Int J Hyg Environ Health 216:710-720. https://doi.org/10.1016/j.ijheh.2013. 01.007

Frederiksen H, Nielsen JK, Morck TA, Hansen PW, Jensen JF, Nielsen O, Andersson AM, Knudsen LE (2013b) Urinary excretion of phthalate metabolites, phenols and parabens in rural and urban Danish mother-child pairs. Int J Hyg Environ Health 216:772-783. https:// doi.org/10.1016/j.ijheh.2013.02.006

Geens T, Apelbaum TZ, Goeyens L, Neels H, Covaci A (2010) Intake of bisphenol A from canned beverages and foods on the Belgian market. Food Addit Contam A 27:1627-1637. https://doi.org/10.1080/ 19440049.2010.508183

Geens T, Goeyens L, Covaci A (2011) Are potential sources for human exposure to bisphenol-A overlooked? Int J Hyg Environ Health 214: 339-347. https://doi.org/10.1016/j.ijheh.2011.04.005

Geens T, Aerts D, Berthot C, Bourguignon J-P, Goeyens L, Lecomte P, Maghuin-Rogister G, Pironnet A-M, Pussemier L, Scippo M-L, Van Loco J, Covaci A (2012a) A review of dietary and non-dietary exposure to bisphenol-A. Food Chem Toxicol 50:3725-3740. https://doi.org/10.1016/j.fct.2012.07.059

Geens T, Goeyens L, Kannan K, Neels H, Covaci A (2012b) Levels of bisphenol-A in thermal paper receipts from Belgium and estimation of human exposure. Sci Total Environ 435-436:30-33. https://doi. org/10.1016/j.scitotenv.2012.07.001

Geens T, Bruckers L, Covaci A, Schoeters G, Fierens T, Sioen I, Vanermen G, Baeyens W, Morrens B, Loots I, Nelen V, de Bellevaux BN, Larebeke NV, Hond ED (2014) Determinants of bisphenol A and phthalate metabolites in urine of Flemish adolescents. Environ Res 134:110-117. https://doi.org/10.1016/j.envres. 2014.07.020

Guidry VT, Longnecker MP, Aase H, Eggesbo M, Zeiner P, ReichbornKjennerud T, Knudsen GP, Bertelsen RJ, Ye X, Calafat AM, Engel SM (2015) Measurement of Total and Free Urinary Phenol and Paraben Concentrations over the Course of Pregnancy: Assessing Reliability and Contamination of Specimens in the Norwegian Mother and Child Cohort Study. Environ Health Perspect 123: 705-711. https://doi.org/10.1289/ehp.1408325

Hagobian T, Smouse A, Streeter M, Wurst C, Schaffner A, Phelan S (2016) Randomized Intervention Trial to Decrease Bisphenol A Urine Concentrations in Women: Pilot Study. J Women's Health 26:128-132. https://doi.org/10.1089/jwh.2016.5746

Hao M, Ding L, Xuan L, Wang T, Li M, Zhao Z, Lu J, Xu Y, Chen Y, Wang W, Bi Y, Xu M, Ning G (2017) Urinary bisphenol A concentration and risk of central obesity in Chinese adults: a prospective study. J Diabetes. https://doi.org/10.1111/1753-0407.12531

Hays SM, Aylward LL, Blount BC (2015) Variation in urinary flow rates according to demographic characteristics and body mass index in NHANES: potential confounding of associations between health outcomes and urinary biomarker concentrations. Environ Health Perspect 123:293-300.https://doi.org/10.1289/ehp.1408944

HBM (2012) Stoffmonographie Bisphenol A (BPA) - Referenz- und Human-Biomonitoring-(HBM)-Werte für BPA im Urin.
Bundesgesundheitsbl 55:1215-1231. https://doi.org/10.1007/ s00103-012-1525-0

Health Canada (2015) Third Report on Human Biomonitoring of Environmental Chemicals in Canada - Results of the Canadian Health Measures Survey Cycle 3 (2012-2013).

Heffernan A, Sly P, Toms L, Hobson P, Mueller J (2014) Bisphenol A exposure is not associated with area-level socioeconomic index in Australian children using pooled urine samples. Environ Sci Pollut Res 21:9344-9355. https://doi.org/10.1007/s11356-014-2882-z

Hehn RS (2016) NHANES Data Support Link between Handling of Thermal Paper Receipts and Increased Urinary Bisphenol A Excretion. Environ Sci Technol 50:397-404. https://doi.org/10. 1021/acs.est.5b04059

Hengstler JG, Foth H, Gebel T, Kramer PJ, Lilienblum W, Schweinfurth H, Völkel W, Wollin KM, Gundert-Remy U (2011) Critical evaluation of key evidence on the human health hazards of exposure to bisphenol A. Crit Rev Toxicol 41:263-291. https://doi.org/10.3109/ 10408444.2011.558487

Hoepner LA, Whyatt RM, Widen EM, Hassoun A, Oberfield SE, Mueller NT, Diaz D, Calafat AM, Perera FP, Rundle AG (2016) Bisphenol A and Adiposity in an Inner-City Birth Cohort. Environ Health Perspect 124:1644-1650. https://doi.org/10.1289/ehp205

ICH (2000) ICH Harmonised Tripartite Guideline: Clinical Investigation of Medicinal Products in the Pediatric Population. http://www.ich. org/products/guidelines/efficacy/efficacy-single/article/clinicalinvestigation-of-medicinal-products-in-the-pediatric-population. html. Accessed 1 Nov 2015

Jaffé M (1986) Ueber den Niederschlag, welchen Pikrinsäure in normalem harn erzeugt und über eine neue reaction des kreatinins. (About the precipitation caused by pikrinic acid in normal urine and about a new reaction of creatinine) [in German]. Physiol Chem 10: $391-400$

Kasper-Sonnenberg M, Wittsiepe J, Koch HM, Fromme H, Wilhelm M (2012) Determination of Bisphenol A in Urine From Mother-Child Pairs-Results From the Duisburg Birth Cohort Study, Germany. J Toxicol Environ Health A 75:429-437. https://doi.org/10.1080/ 15287394.2012.674907

Kasper-Sonnenberg M, Koch HM, Wittsiepe J, Brüning T, Wilhelm M (2014) Phthalate metabolites and bisphenol A in urines from German school-aged children: Results of the Duisburg Birth Cohort and Bochum Cohort Studies. Int J Hyg Environ Health 217:830-838. https://doi.org/10.1016/j.ijheh.2014.06.001

Koch HM, Calafat AM (2009) Human body burdens of chemicals used in plastic manufacture. Philos Trans R Soc B 364:2063-2078. https:// doi.org/10.1098/rstb.2008.0208

Koch HM, Becker K, Wittassek M, Seiwert M, Angerer J, KolossaGehring M (2007) Di-n-butylphthalate and butylbenzylphthalate urinary metabolite levels and estimated daily intakes: pilot study for the German Environmental Survey on children. J Expo Sci Environ Epidemiol 17:378-387. https://doi.org/10.1038/sj.jes. 7500526

Koch HM, Wittassek M, Brüning T, Angerer J, Heudorf U (2011) Exposure to phthalates in 5-6 years old primary school starters in Germany - A human biomonitoring study and cumulative risk assessment. Int J Hyg Environ Health 214:188-195. https://doi.org/10. 1016/j.ijheh.2011.01.009

Koch HM, Kolossa-Gehring M, Schröter-Kermani C, Angerer J, Brüning $\mathrm{T}$ (2012) Bisphenol A in $24 \mathrm{~h}$ urine and plasma samples of the German Environmental Specimen Bank from 1995 to 2009: A retrospective exposure evaluation. J Expo Sci Environ Epidemiol 22: 610-616. https://doi.org/10.1038/jes.2012.39

Lakind JS, Naiman DQ (2011) Daily intake of bisphenol A and potential sources of exposure: 2005-2006 National Health and Nutrition Examination Survey. J Expo Sci Environ Epidemiol 21:272-279. https://doi.org/10.1038/jes.2010.9 
LaKind JS, Naiman DQ (2015) Temporal trends in bisphenol A exposure in the United States from 2003-2012 and factors associated with BPA exposure: Spot samples and urine dilution complicate data interpretation. Environ Res 142:84-95. https://doi.org/10.1016/j. envres.2015.06.013

Lang IA, Galloway TS, Scarlett A et al (2008) Association of urinary bisphenol a concentration with medical disorders and laboratory abnormalities in adults. JAMA 300:1303-1310. https://doi.org/10. 1001/jama.300.11.1303

Larsson K, Ljung Björklund K, Palm B, Wennberg M, Kaj L, Lindh CH, Jönsson BAG, Berglund M (2014) Exposure determinants of phthalates, parabens, bisphenol A and triclosan in Swedish mothers and their children. Environ Int 73:323-333. https://doi.org/10.1016/ j.envint.2014.08.014

Lewis RC, Meeker JD, Peterson KE, Lee JM, Pace GG, Cantoral A, TéllezRojo MM (2013) Predictors of urinary bisphenol A and phthalate metabolite concentrations in Mexican children. Chemosphere 93: 2390-2398. https://doi.org/10.1016/j.chemosphere.2013.08.038

Li D-K, Miao M, Zhou Z, Wu C, Shi H, Liu X, Wang S, Yuan W (2013a) Urine Bisphenol-A Level in Relation to Obesity and Overweight in School-Age Children. PLoS One 8:e65399. https://doi.org/10.1371/ journal.pone.0065399

Li X, Ying G-G, Zhao J-L, Chen Z-F, Lai H-J, Su H-C (2013b) 4Nonylphenol, bisphenol-A and triclosan levels in human urine of children and students in China, and the effects of drinking these bottled materials on the levels. Environ Int 52:81-86. https://doi. org/10.1016/j.envint.2011.03.026

Lopez-Espinosa MJ, Granada A, Araque P, Molina-Molina JM, Puertollano MC, Rivas A, Fernandez M, Cerrillo I, Olea-Serrano MF, Lopez C, Olea N (2007) Oestrogenicity of paper and cardboard extracts used as food containers. Food Addit Contam 24:95-102. https://doi.org/10.1080/02652030600936375

Lotz A, Kendzia B, Gawrych K, Lehnert M, Brüning T, Pesch B (2013) Statistical methods for the analysis of left-censored variables. GMS Med Inform Biom Epidemiol 9:1-7. https://doi.org/10.3205/ mibe000133

Lv Y, Lu S, Dai Y, Rui C, Wang Y, Zhou Y, Li Y, Pang Q, Fan R (2017) Higher dermal exposure of cashiers to BPA and its association with DNA oxidative damage. Environ Int 98:69-74. https://doi.org/10. 1016/j.envint.2016.10.001

Mansilha C, Silva P, Rocha S, Gameiro P, Domingues V, Pinho C, Ferreira IMPLVO (2013) Bisphenol A migration from plastic materials: direct insight of ecotoxicity in Daphnia magna. Environ Sci Pollut Res 20:6007-6018. https://doi.org/10.1007/s11356-0131614-0

Meeker JD, Ehrlich S, Toth TL, Wright DL, Calafat AM, Trisini AT, Ye $X$, Hauser R (2010) Semen quality and sperm DNA damage in relation to urinary bisphenol A among men from an infertility clinic. Reprod Toxicol 30:532-539. https://doi.org/10.1016/j.reprotox. 2010.07.005

Noonan GO, Ackerman LK, Begley TH (2011) Concentration of Bisphenol A in Highly Consumed Canned Foods on the U.S. Market. J Agric Food Chem 59:7178-7185. https://doi.org/10. 1021/jf201076f

Quirós-Alcalá L, Eskenazi B, Bradman A, Ye X, Calafat AM, Harley K (2013) Determinants of urinary bisphenol A concentrations in Mexican/Mexican-American pregnant women. Environ Int 59: 152-160. https://doi.org/10.1016/j.envint.2013.05.016

Remer T, Neubert A, Maser-Gluth C (2002) Anthropometry-based reference values for 24-h urinary creatinine excretion during growth and their use in endocrine and nutritional research. Am J Clin Nutr 75: 561-569

Rubin BS (2011) Bisphenol A: An endocrine disruptor with widespread exposure and multiple effects. J Steroid Biochem Mol Biol 127:2734. https://doi.org/10.1016/j.jsbmb.2011.05.002
Rudel RA, Gray JM, Engel CL, Rawsthorne TW, Dodson RE, Ackerman JM, Rizzo J, Nudelman JL, Brody JG (2011) Food packaging and bisphenol A and bis(2-ethyhexyl) phthalate exposure: findings from a dietary intervention. Environ Health Perspect 119:914-920. https://doi.org/10.1289/ehp.1003170

Sathyanarayana S, Alcedo G, Saelens BE, Zhou C, Dills RL, Yu J, Lanphear B (2013) Unexpected results in a randomized dietary trial to reduce phthalate and bisphenol A exposures. J Expo Sci Environ Epidemiol23:378-384.https://doi.org/10.1038/jes.2013.9

Schindler BK, Esteban M, Koch HM, Castano A, Koslitz S, Cañas A, Casteleyn L, Kolossa-Gehring M, Schwedler G, Schoeters G, Hond ED, Sepai O, Exley K, Bloemen L, Horvat M, Knudsen LE, Joas A, Joas R, Biot P, Aerts D, Lopez A, Huetos O, Katsonouri A, MaurerChronakis K, Kasparova L, Vrbík K, Rudnai P, Naray M, Guignard C, Fischer ME, Ligocka D, Janasik B, Reis MF, Namorado S, Pop C, Dumitrascu I, Halzlova K, Fabianova E, Mazej D, Tratnik JS, Berglund M, Jönsson B, Lehmann A, Crettaz P, Frederiksen H, Nielsen F, McGrath H, Nesbitt I, De Cremer K, Vanermen G, Koppen G, Wilhelm M, Becker K, Angerer J (2014) The European COPHES/DEMOCOPHES project: Towards transnational comparability and reliability of human biomonitoring results. Int $\mathbf{J}$ Hyg Environ Health 217:653-661. https://doi.org/10.1016/j.ijheh. 2013.12.002

Shankar A, Teppala S, Sabanayagam C (2012) Urinary Bisphenol A Levels and Measures of Obesity: Results from the National Health and Nutrition Examination Survey 2003-2008. ISRN Endocrinoly 2012:1-6. https://doi.org/10.5402/2012/965243

Søeborg T, Frederiksen H, Andersson A-M (2014) Considerations for estimating daily intake values of nonpersistent environmental endocrine disruptors based on urinary biomonitoring data. Reproduction 147:455-463. https://doi.org/10.1530/rep-13-0458

Tai X, Chen Y (2016) Urinary bisphenol A concentrations positively associated with glycated hemoglobin and other indicators of diabetes in Canadian men. Environ Res 147:172-178. https://doi.org/10. 1016/j.envres.2016.02.006

Teeguarden JG, Hanson-Drury S (2013) A systematic review of Bisphenol A "low dose" studies in the context of human exposure: A case for establishing standards for reporting "low-dose" effects of chemicals. Food Chem Toxicol 62:935-948. https://doi.org/10. 1016/j.fct.2013.07.007

Teeguarden JG, Calafat AM, Ye X, Doerge DR, Churchwell MI, Gunawan R, Graham MK (2011) Twenty-Four Hour Human Urine and Serum Profiles of Bisphenol A during High-Dietary Exposure. Toxicol Sci 123:48-57. https://doi.org/10.1093/toxsci/ kfr160

Teeguarden J, Hanson-Drury S, Fisher JW, Doerge DR (2013) Are typical human serum BPA concentrations measurable and sufficient to be estrogenic in the general population? Food Chem Toxicol 62:949963. https://doi.org/10.1016/j.fct.2013.08.001

Teeguarden JG, Twaddle NC, Churchwell MI, Yang X, Fisher JW, Seryak LM, Doerge DR (2015a) 24-hour human urine and serum profiles of bisphenol A following ingestion in soup: Individual pharmacokinetic data and emographics. Data Brief 4:83-86. https://doi.org/10. 1016/j.dib.2015.03.002

Teeguarden JG, Twaddle NC, Churchwell MI, Yang X, Fisher JW, Seryak LM, Doerge DR (2015b) 24-hour human urine and serum profiles of bisphenol A: Evidence against sublingual absorption following ingestion in soup. Toxicol Appl Pharmacol 288:131-142. https://doi. org/10.1016/j.taap.2015.01.009

Teitelbaum SL, Britton JA, Calafat AM, Ye X, Silva MJ, Reidy JA, Galvez MP, Brenner BL, Wolff MS (2008) Temporal variability in urinary concentrations of phthalate metabolites, phytoestrogens and phenols among minority children in the United States. Environ Res 106:257-269. https://doi.org/10.1016/j.envres.2007.09.010

Trasande L, Attina TM, Blustein J (2012) Association between urinary Bisphenol A concentration and obesity prevalence in children and 
adolescents. JAMA 308:1113-1121. https://doi.org/10.1001/2012. jama.11461

Vafeiadi M, Roumeliotaki T, Myridakis A, Chalkiadaki G, Fthenou E, Dermitzaki E, Karachaliou M, Sarri K, Vassilaki M, Stephanou EG, Kogevinas M, Chatzi L (2016) Association of early life exposure to bisphenol A with obesity and cardiometabolic traits in childhood. Environ Res 146:379-387. https://doi.org/10.1016/j.envres.2016. 01.017

Vandenberg LN, Maffini MV, Sonnenschein C, Rubin BS, Soto AM (2009) Bisphenol-A and the Great Divide: A Review of Controversies in the Field of Endocrine Disruption. Endocr Rev 30:75-95. https://doi.org/10.1210/er.2008-0021

Vandenberg LN, Chahoud I, Heindel JJ, Padmanabhan V, Paumgartten FJR, Schoenfelder G (2010) Urinary, Circulating, and Tissue Biomonitoring Studies Indicate Widespread Exposure to Bisphenol A. Environ Health Perspect 118:1055-1070. https://doi. org/10.1289/ehp.0901716

Vandenberg LN, Hunt PA, Myers JP, vom Saal FS (2013) Human exposures to bisphenol A: mismatches between data and assumptions. Rev Environ Health 28:37. https://doi.org/10.1515/reveh-20120034

Vitku J, Heracek J, Sosvorova L, Hampl R, Chlupacova T, Hill M, Sobotka V, Bicikova M, Starka L (2016) Associations of bisphenol A and polychlorinated biphenyls with spermatogenesis and steroidogenesis in two biological fluids from men attending an infertility clinic. Environ Int 89-90:166-173. https://doi.org/10.1016/j. envint.2016.01.021

Völkel W (2017) Why did researchers not use realistic doses in animal studies of bisphenol A? Arch Toxicol 91:1519-1522. https://doi.org/ 10.1007/s00204-016-1840-6

Völkel W, Colnot T, Csanády GA, Filser JG, Dekant W (2002) Metabolism and Kinetics of Bisphenol A in Humans at Low Doses Following Oral Administration. Chem Res Toxicol 15: 1281-1287. https://doi.org/10.1021/tx025548t

Völkel W, Bittner N, Dekant W (2005) Quantitation of bisphenol A and bisphenol A glucuronide in biological samples by high performance liquid chromatography-tandem mass spectrometry. Drug Metab Dispos 33:1748-1757.https://doi.org/10.1124/dmd.105.005454

Völkel W, Kiranoglu M, Fromme H (2008) Determination of free and total bisphenol A in human urine to assess daily uptake as a basis for a valid risk assessment. Toxicol Lett 179:155-162. https://doi.org/ 10.1016/j.toxlet.2008.05.002

vom Saal FS, Welshons WV (2014) Evidence that bisphenol A (BPA) can be accurately measured without contamination in human serum and urine, and that BPA causes numerous hazards from multiple routes of exposure. Mol Cell Endocrinol 398:101-113. https://doi.org/10. 1016/j.mce.2014.09.028

Vrijheid M, Casas M, Gascon M, Valvi D, Nieuwenhuijsen M (2016) Environmental pollutants and child health-A review of recent concerns. Int J Hyg Environ Health 219:331-342. https://doi.org/10. 1016/j.ijheh.2016.05.001

Wang HX, Zhou Y, Tang CX, Wu JG, Chen Y, Jiang QW (2012) Association between bisphenol A exposure and body mass index in Chinese school children: a cross-sectional study. Environ Health 11:79-79. https://doi.org/10.1186/1476-069X-11-79

WHO (1996) Biological monitoring of chemical exposure in the workplace: guidelines. http://apps.who.int/iris/bitstream/10665/41856/1/ WHO_HPR_OCH_96.1.pdf. Accessed 8 Mar 2017

WHO (2007) Growth reference 5-19 years - Body mass index. http:// www.who.int/growthref/who2007_bmi_for_age/en/. Accessed 6 Jan 2017

Wittassek M, Heger W, Koch HM, Becker K, Angerer J, KolossaGehring M (2007) Daily intake of di(2-ethylhexyl)phthalate (DEHP) by German children - A comparison of two estimation models based on urinary DEHP metabolite levels. Int $\mathrm{J}$ Hyg Environ Health 210:35-42. https://doi.org/10.1016/j.jheh.2006.11. 009

Wolff MS, Teitelbaum SL, Windham G, Pinney SM, Britton JA, Chelimo C, Godbold J, Biro F, Kushi LH, Pfeiffer CM, Calafat AM (2007) Pilot study of urinary biomarkers of phytoestrogens, phthalates, and phenols in girls. Environ Health Perspect 115:116-121. https://doi. org/10.1289/ehp. 9488

Yang X, Doerge DR, Teeguarden JG, Fisher JW (2015) Development of a physiologically based pharmacokinetic model for assessment of human exposure to bisphenol A. Toxicol Appl Pharmacol 289:442456. https://doi.org/10.1016/j.taap.2015.10.016

Ye X, Wong L-Y, Kramer J, Zhou X, Jia T, Calafat AM (2015) Urinary Concentrations of Bisphenol A and Three Other Bisphenols in Convenience Samples of U.S. Adults during 2000-2014. Environ Sci Technol 49:11834-11839. https://doi.org/10.1021/acs.est. $5 \mathrm{~b} 02135$

Zhang Z, Alomirah H, Cho HS, Li YF, Liao C, Minh TB, Mohd MA, Nakata H, Ren N, Kannan K (2011) Urinary bisphenol A concentrations and their implications for human exposure in several Asian countries. Environ Sci Technol 45:7044-7050. https://doi.org/10. 1021/es200976k 